Mariusz Robert Drozdowski

Uniwersytet w Białymstoku

barok1@autograf.pl

\title{
Postulaty religijne w wystąpieniach kozackich pierwszej połowy XVII wieku
}

\begin{abstract}
Drozdowski Mariusz Robert, Postulaty religijne w wystapieniach kozackich pierwszej polowy XVII wieku (The Religious Aspects of the Cossacks' Uprisings in the First Half of $17^{\text {th }}$ Century). "Poznańskie Studia Slawistyczne"10. Poznań 2016. Publishing House of the Poznań Society for the Advancement of the Arts and Sciences, pp. 85-98. ISSN 2084-3011.

This paper focuses mostly on the religious aspects of the Cossacks' uprisings in the first half of $17^{\text {th }}$ century (mainly the $1625,1630,1637$ and 1638 uprisings), and discusses their impact on the origins, the course and following peace negotiations as well. The paper is based mostly on Cossack primary sources like manifestos, proclamations issued by the leaders, together with the directions which were to be followed during the peace talks, and the not Cossack sources as well. They prove how the religious aspects, namely the appeals to defend the persecuted orthodox confession, contributed to the character of the developments. Another question was, to what extent the religious engagement of the Cossacks uprisings at that time was caused by a sincere concern for the Orthodox Church situation, or perhaps there were other reasons, not having much in common with the faith. The analysis discusses also the Cossack delegates' actions and policy on the Commonwealth Sejm in the years 1631-33, during which they firmly demanded restoration of the status the Orthodox Church had before 1596.
\end{abstract}

Keywords: the Cossacks; religion; the Orthodox Church; uprising; rebellion; Polish-Lithuanian Commonwealth

Pojawienie się Kozaczyzny zaporoskiej na arenie dziejów było jednym z tych wydarzeń, które w istotny sposób wpłynęły na losy Rzeczypospolitej. Postępujący od drugiej połowy XVI wieku proces przemiany Zaporożców w świadomy swych praw i przywilejów oraz odrębności narodowej stan społeczny poważnie zagrażał stabilności jej ustroju społecznego, politycznego i terytorialnego (Щербак 2000: 300; Drozdowski, Chynczewska-Hennel 2008: 165-221). Nie mniejszym niebezpieczeństwem było także stopniowe zyskiwanie przez Kozaków statusu jednej z ważniejszych sił w walce o społeczne, narodowościowe, a przede wszystkim religijne interesy ukraińskiej wspólnoty. 
Czynnikiem, który w zasadniczy sposób przyczynił się do wkroczenia Kozaków na arenę walk religijnych w państwie, były ustalenia unii brzeskiej (1596) dzielące społeczność prawosławną na dwa zwalczające się obozy: prawosławny i unicki (Wójcik 1961: 76-77; Chynczewska-Hennel 1994: 28-34; Mironowicz 1997: 17-18; Kempa 2007: 57-113). Wpłynęły one na rozwój religijności Kozaczyzny i przekonania o przynależności do Kościoła wschodniego (Drozdowski 2008: 66-235).

Według Franka Sysyna, elita kozacka początków XVII wieku przekształciła Kozaków w żołnierzy walczących o prawa i wolności zlikwidowanej oficjalnie Cerkwi greckiej i porównywanych przez kler do wojów księcia Olega (Sysyn 1982: 80). Pierwsze wystąpienie w obronie prześladowanego Kościoła prawosławnego miało miejsce podczas powstania z roku 1625 (Mironowicz 2001: 94) pod wodzą hetmana Marka Żmajły (v. Рудницький 1897: 1-48; Жукович 1910: 2-33; Chodynicki 1934: 459-461; Wójcik 1961: 102, 1989: 51-53; Serczyk 1984: 256, 258-261; Chynczewska-Hennel 1985: 101; Щербак 1989: 23-27; Грушевський 1995a: 541-561; Floria 1998: 27-42; Plokhy 2001: 134-135; Drozdowski 2008: 175-183; Kroll, Nagielski, Wagner 2010: 155-156; Брехуненко 2011: 162, 184, 292, 433, 437). Choć u podstaw konfliktu legło zaangażowanie się Kozaków po stronie braci Gerejów, Mehmeda i Szahina, w walce z Turcją o utrzymanie władzy na Krymie (szerzej: Грушевський 1995a: 512-527), to konflikt zaogniało nieuregulowanie przez władze państwowe postulatu ,uspokojenia religii greckiej” i dalsze ograniczanie jej praw.

Wyrazem zdecydowanego sprzeciwu Kozaków wobec uprzywilejowania Kościoła katolickiego była krwawa rozprawa z wójtem kijowskim Teodorem Chodyką, zwolennikiem unii (Kempa 2003: 289-296; Drozdowski 2004: 379-388). Kontynuacją przyjętej linii postępowania była prośba o zachowanie „w pokoju religii greckiej”, wniesiona na sejm 1625 roku. Zdaniem Zygmunta III Wazy, zaangażowanie Zaporożców w politykę religijną, w której jedną ze stron był patriarchat Konstantynopola w granicach Turcji, miało charakter antypaństwowy, dlatego usiłował ograniczyć działania na tym polu ${ }^{1}$. W jednym $\mathrm{z}$ listów domagał się wymuszenia na

${ }^{1}$ Wśród punktów mających uspokoić wrzenie na Zaporożu był m.in. obowiązek przebywania Kozaków tylko na wyznaczonym terenie, bezwzględne podporządkowanie się 
Zaporożcach: „aby w duchowne obrzędy nie wdawali się, protekcji ludzi pod pretekstem duchowieństwa praktyki z cudzoziemcami czyniących władicze tytuły, imć wolą i podanie J.K.M. swawolnie sobie uzurpujących aby odstąilil”'2.

Wraz z przybyciem na Ukrainę armii koronnej Koniecpolskiego (połowa września 1625 roku; Jakowenko 2000: 198), której Kozacy przeciwstawili się zbrojnie (Serczyk 1984: 259), pojawiły się pogłoski, że głównym celem wyprawy było wzmocnienie Kościoła katolickiego. Niejaki pop Filip twierdził, że hetman przybył do Białej Cerkwi: „чтобъ козаковъ уменшить, а уменша козаковъ и въра римская въ Киеве и во всђхъ литовскихъ городехъ учинитъ” (Кулиш 1877: 181).

Kwestie religijne poruszono także w rozpoczętych pod koniec października rozmowach między skonfliktowanymi stronami. Komisarze królewscy, wypełniając wolę władcy (v. tzw. Deklarację Jego Królewskiej Mości, Niemcewicz 1833: 177-186; Грушевський 1995a: 547), żądali zaniechania przez Kozaków kontaktów z Turcją przez osoby duchowne, wśród których jedna podawała się za samego patriarchę jerozolimskiego ${ }^{3}$, zakazali naruszania kompetencji króla w sprawie mianowania wyższej hierarchii cerkiewnej, mieszania się do spraw kościelnych ${ }^{4}$. Kozacy odrzucili zaproponowane warunki ugody wraz z żądaniami natury religijnej. Wśród próśb, od których uzależnili powrót do posłuszeństwa wobec Rzeczypospolitej, ponownie znalazł się postulat „uspokojenia religii greckiej"s. W konsekwencji hetman Koniecpolski podjął decyzję o dalszych działaniach zbrojnych (Жукович 1910: 9-10; Serczyk 1984: 261-262). Gdy żadna ze stron nie zdołała odnieść wyraźnego zwycięstwa,

jurysdykcji hetmańskiej i władz miejscowych, zakaz przyjmowania zbiegów z obcych państw oraz wchodzenia $\mathrm{z}$ tymi państwami w jakiekolwiek kontakty bez zgody króla (Serczyk 1984: 258).

${ }^{2}$ Biblioteka Książąt Czartoryskich w Krakowie (dalej: BCz.), rkps 117, s. 256.

${ }^{3}$ „Urażać to J.K.M. musi, że ludzie rozmaite duchowne (taki był on, co się zwał Patriarchą Jerozolimskim), iako i rozmaite Impostory (...) przyjmują" (Niemcewicz 1833: 179).

${ }^{4}$ „I to, że przeciwko władzy J.K.Mci poddawania za żywota tych, którzy w dawnem używaniu prawa swego byli, drugie metropolity i władyki nasadzają, co i teraz świeżo, po zawarciu archymandryty, drugiego z tego właśnie monastyru" (Niemcewicz 1833: 179; Грушевський 1995а: 547).

${ }^{5}$ Deklaracja Kozaków Zaporoskich na tę deklaracją woli Króla Jegomości w kole wszystkiego Wojska Zaporoskiego (Niemcewicz 1833: 188-198). 
wznowiono rozmowy pokojowe (Serczyk 1984: 261-262; Wójcik 1989: 52; Грушевський 1995a: 553-561). Istotną rolę odgrywały w nich kwestie religijne ${ }^{6}$. Zaporożcy pisali do komisarzy:

Więc iż kilka próśb swych tymże posłańcom swym zleciliśmy wnieść w pośrodek WM. naszych miłościwych PP. nam bardzo potrzebnych, iako o uspokojenie religii (na co król J.M.P.N. mił. dawna zezwolić raczył), o poprawę wolności naszych, o podniesienie żołdu dorocznego ${ }^{7}$.

Prośbę o przywrócenie należnych praw wyznaniu prawosławnemu odnajdujemy także w instrukcji dla posłów kozackich:

wejrzawszy na powolność nasze i chcąc nas ochotniejszymi do usługiwania Rzeczypospolitej mieć, do j. kr. m. pana naszego miłościwego przyczynę zanieść, aby król J. m. p. n. m. starożytną religię naszą grecką uspokoiwszy, nas przy wolnościach naszych od przodków ich mość królów naszych polskich św. pamięci zeszłych i teraźniejszego króla J. m. p. n. m. za wieczne posługi nasze, nadanych, z poprawą onych całe i nienaruszenie zachować raczył

Na uroczysku Niedźwiedzie Łozy 6 listopada 1625 roku podpisano ugodę, zwaną kurukowską ${ }^{9}$ Brak w jej tekście jakichkolwiek nawiązań do spraw Kościoła prawosławnego. Mogło to wynikać z wcześniejszego polubownego załatwienia problemu, którego królewscy wysłannicy w ogóle zdawali się nie dostrzegać ${ }^{10}$. W kondycjach danych Zaporożcom 4 listopada, na dwa dni przed podpisaniem ordynacji kurukowskiej, pisano: „Co się tyczy proźb wniesionych: nie wątpią Jchmć Panowie Komisarze, że się im w religii ich greckiej, żadne nie dzieje się praejudicium i przeszkoda" (Niemcewicz 1833: 214). Dziwiono się ponadto, że ,ludzi rycerskich” zajmują sprawy duchowe, regulowane przecież przez odpowiednie ustawy sejmu (Niemcewicz 1833: 214).

Mimo że ugoda kurukowska kończyła zbrojne starcie z 1625 roku,

\footnotetext{
${ }^{6} \mathrm{Na}$ fakt ten zwrócili również uwagę: Chynczewska-Hennel 1985: 101; Plokhy 2001: $134-135$.

${ }^{7}$ List od Kozaków do komisarzy królewskich, 3 listopad 1625 roku (Niemcewicz 1833 : 200).

${ }^{8}$ Instrukcja dla posłów od Wojska Zaporoskiego (Przeździecki, Malinowski 1844: 182).

${ }^{9}$ Bardziej szczegółowo: Serczyk 1984: 263; Грушевський 1995a: 558-561; Jakowenko 2000: 198-199.

${ }^{10}$ Plokhy twierdzi, że Kozacy przy końcu negocjacji poświęcili kwestie religijne na rzecz uregulowania spraw rejestru czy żołdu (2001: 135).
} 
to nie stworzyła warunków do rozwiązania problemu kozackiego ani do zadowalającego uporządkowania spraw „religii greckiej” (Serczyk 1984: 264). Kolejnym zbrojnym wystąpieniem Kozaków, będącym konsekwencją ignorowania przez władze Rzeczypospolitej ich problemów ${ }^{11}$, było powstanie z 1630 roku, którym dowodził Taras Fedorowicz. Wśród różnych punktów spornych ponownie pojawił się problem funkcjonowania Kościoła prawosławnego ${ }^{12}$. Wraz z przybyciem na Ukrainę armii koronnej po zakończeniu wojny ze Szwecją ${ }^{13}$ do Kozaków zaczęły docierać pogłoski, jakoby wojsko zostało przysłane, by wykorzenić wyznanie prawosławne. Czytamy o tym np. w Kronice... Pawła Piaseckiego:

kozacy za pobuntowaniem archymandryty kijowskiego syzmatyka twierdzonego, że całe wojsko Pruskie na wykorzenienie kozaków i wiary błachoczystywej ciongnie na Ukrainę, na kwaterach rozłożone napadłszy porospendzali, tabory onych porabowali, i nie mało z onych pozabijali ludzi (Wójcicki 1846: 154; Piasecki 1870: 346).

Gdzieniegdzie obawiano się, że armia zacznie wydalać ludność ruską do Moskwy, co odnotował autor Latopisu Lwowskiego: „Жолніре до Києва приїхали с тим інтентом аби впрод козаков, а затим во вшисткой Україні русь вистинати аж до Москви" (Бевзо 1971: 105, 14-15). Nie można zatem całkowicie wykluczyć antyprawosławnych tendencji w działalności wojsk koronnych.

Relacja wojewodów putywlskich $\mathrm{z}$ maja 1630 roku zawiera informację, że w przededniu wybuchu powstania do obozu kozackiego przybył specjalny wysłannik patriarchy jerozolimskiego Teofanesa, Andrzej.

${ }^{11}$ Żądano zwiększenia rejestru, wypłaty zaległego żołdu, powstrzymania szlachty od nasilających się prześladowań, zatwierdzenia hierarchii prawosławnej. V. Tomkiewicz 1930a: 104-128; Грушевський 1995b: 100-120; Лях 2002b: 391-392.

${ }^{12}$ Wśród historyków ukraińskich znaczenie kwestii religijnych podkreśla: Жукович 1911: 777- 802, 987-1007; Щербак 1989: 28-43; Грушевський 1995b: 100-101; Plokhy 2001: 136. Wśród historyków polskich: Tomkiewicz 1930a: 104-128; Lewicki 1934: 19; Serczyk 1984: 302; Chynczewska-Hennel 1985: 102; Franz 2006: 181-184; Drozdowski 2008: $183-192$.

Według Chodynickiego, siłom zewnętrznym, przede wszystkim Moskwie i Turcji, zależało na rozpowszechnianiu wieści o prześladowaniach religijnych Zaporożców (1934: 532). Wójcik twierdził, że ,prawosławie pchało w swej obronie Kozaków do walki z Rzeczypospolitą, a Kozacy religii żadnej chętnie do tej walki stawali” (1961: 108).

${ }^{13}$ Wojsko dopuszczało się grabieży i przemocy na nierejestrowych Kozakach, co radykalizowało nastroje (Serczyk 1984: 302). 
Przywiózł list, w którym patriarcha udzielał Zaporożcom błogosławieństwa, namawiał do trwania przy ,religii greckiej” i nakłaniał do podporządkowania się carowi moskiewskiemu ${ }^{14}$.

Niezależnie od politycznego wymiaru misji wysłannika Teofanesa, można przypuszczać, że jego obecność w szeregach Kozaków w dużym stopniu przyczyniła się do umocnienia w nich woli walki za Cerkiew prawosławną. Świadectwo temu dadzą późniejsze uniwersały hetmana Fedorowicza.

Do dalszego wzrostu niezadowolenia Kozaków przyczyniła się działalność „starszego” rejestru, Hrycka Czarnego (Коробов 2002: 542). Pragnąc przywrócić spokój na Zaporożu, wystosował on w listopadzie 1629 roku pismo, w którym zażądał od Kozaków zaprzestania wypraw morskich, bezwzględnego podporządkowania się postanowieniom ugody kurukowskiej i swojej władzy. Wobec zdecydowanej odmowy Czarny w porozumieniu z hetmanem Koniecpolskim przeprowadził rewizję rejestru, wykreślając $\mathrm{z}$ niego wszystkich, którzy odmówili mu posłuszeństwa (Ляx 2002b: 391-392). Rozgoryczeni Zaporożcy w styczniu 1630 roku oddali buławę hetmańską Fedorowiczowi, a Czarnego ścięli (Wójcik 1961: 107).

Okoliczności śmierci przełożonego wojsk rejestrowych, która była również wyrazem buntu przeciw władzy Rzeczypospolitej, powiązano z wątkiem religijnym. Autor Latopisu Lwowskiego zapewnia, że impuls do zamordowania Hrycki Czarnego dało jego przejście na unię: „Козаки вишовши з Запорожжа, i того Гриська гетьмана, же зле пінязі, рекомо, поділил, котрий на унію бул присягл, сам ся признал, которого стято" (Бевзо 1971: 106).

Nie wszyscy historycy uznają religijne motywacje Kozaków, powołując się na brak odpowiednich zapisów w dokumencie kończącym powstanie 1630 roku. Dowodzi ich jednak szereg świadectw - np. opinia hetmana Koniecpolskiego:

Napłynęły do nich [Kozaków - M.R.D.] listy od niektórych osób, tak duchownych, jak świeckich religiej greckiej, w których powiadamiali, że ich wiarę znoszą [Polacy M.R.D.], cerkwie niszczą, prosząc aby się przy wierze swojej oponowali. Namowy te

${ }^{14}$ Wątek moskiewski w powstaniu omawia Floria (1992: 167-171). Zdaniem hetmana Koniecpolskiego, przyczyną postulatów religijnych w buncie Fedorowicza była też proprawosławna agitacja Moskwy (Plokhy 2001: 140). 
rozdrażniły czerń i całą Ukrainę poruszyły tak, że nikt z tamtejszych obywateli nie był bezpieczny w swoim domu. Wydało zaraz swawoleństwo uniwersały, że o wiarę idzie, kto był kiedykolwiek Kozakiem i nim chce być, aby się kupił, wszystkie wolności dawne, a raczej swawole obiecując. W krótkim czasie zebrało się kilkadziesiąt tysięcy (cyt. za Tomkiewicz 1930b: 7-8).

Również pisma Tarasa Fedorowicza wzywają do walki w imię zagrożonych praw Kościoła prawosławnego, potwierdzonych Opisaniem sprawy wojennej, która się toczyła z Kozakami pod Perejasławiem: „Taras hetman kozacki rozpisał po wszystkiej Ukrainie i po innej wszystkiej Rusi, aby kto się odzywa być wiary greckiej do Wojska Zaporoskiego się ściągali, a przejścia lachom bronili"'15.

Wymowne są także przytaczane przez Latopis Lwowski słowa Koniecpolskiego wypowiedziane po zakończeniu działań zbrojnych: „Ото ж унія - лежить русь с поляками!” (Бевзо 1971: 110). Powstanie zakończyło się zawarciem ugody, zwanej perejasławską (Serczyk 1984: 305; Грушевський 1995b: 108-113).

Wydaje się, że fakt nieporuszenia przez Kozaków w pertraktacjach pokojowych kwestii związanych z „uspokojeniem religii greckiej” w głównej mierze wynikał z postawy przedstawicieli Rzeczypospolitej, którzy znowu nie widzieli jakichkolwiek form prześladowania wiernych Kościoła prawosławnego ${ }^{16}$. Dlatego, jak sądzę, po zakończeniu rokowań na radzie w Czerkasach, w której uczestniczył nieoficjalny metropolita Borecki, postanowili wysłać poselstwo do króla, domagając się przyznania wszelkich swobód wyznaniowych (Жукович 1911: 999; Plokhy 2001: 140).

Wyrazem ciągłości podejmowanych przez Kozaczyznę starań na rzecz swego Kościoła jest udział jej przedstawicieli na sejmach w latach 1631-1633, podczas których ze szczególną ostrością upominali się o przywrócenie Cerkwi statusu sprzed 1596 roku. Mimo że konstytucja sejmowa z 17 marca 1635 roku ostatecznie potwierdziła swobody wyznaniowe Kościołowi wschodniemu (Ohryzko 1859: 407), Kozaczyzna nie porzuciła spraw religijnych. Zarówno bowiem w wystąpieniu pod wodzą Pawluka,

${ }^{15}$ Zeznanie uczestnika buntu (AGAD, AR. dz. II, nr 1025, b. p.)

${ }^{16}$, ,...) niewinnych ludzi z domów, od gospodarstw ich i od robót, praetextem łamania wiary, w której się nikomu krzywda nie dzieje, tak wiele z uciążeniem tych tu krajów zbawiali i dotąd wielkiego krwie rozlania przyczyną byli” (Крип’якевич 1908: 345). 
jak i Ostrzanina (Ostranicy) pojawiły się hasła walki w obronie „religii greckiej”.

Ponieważ bezpośrednie przyczyny pierwszego z wymienionych „buntów" są dość wyczerpująco omówione w literaturze przedmiotu ${ }^{17}$, warto jedynie wspomnieć, że istotny wpływ na radykalizację nastrojów czerni kozackiej miało porozumienie między Rzecząpospolitą a Kozakami rejestrowymi z maja 1637 roku (szerzej: Sysyn 1985: 82-84). Kozacy w zamian za wypłatę zaległego żołdu potwierdzili postanowienia ugody kurukowskiej i zgodzili na rewizję rejestru, do którego wpisywano tylko Zaporożców lojalnych wobec Rzeczypospolitej (Wójcik 1961: 118). W odpowiedzi na układ na początku czerwca tego roku Pawluk po najeździe na Korsuń zagarnął znajdującą się tam artylerię kozacką i sprowadził ją na Zaporoże. Akcja watażki, której konsekwencją było odsunięcie od władzy ugodowej starszyzny i przejęcie pełnej kontroli na Zadnieprzu (Ляx 2002c: 392), oznaczała jawny bunt wobec Rzeczypospolitej. Również $\mathrm{w}$ tym wystąpieniu podnoszono kwestie religijne ${ }^{18}$. Wskazują na to uniwersały przywódców kozackich $\mathrm{m}$. in. w diariuszu konfliktu pióra uczestnika wydarzeń księdza Szymona Okolskiego (Okolski 1858a: 26-27).

Pogłoski o przybyciu na Ukrainę armii koronnej na leże zimowe (Plokhy 2001: 141) spowodowały wydanie przez pułkownika Pawła Skidana uniwersału, w którym przestrzegał przed zagrożeniem dla „religii greckiej"19. W kolejnej odezwie, z 24 października (Okolski 1858a: 26), podkreślał złowrogie nastawienie wojska do wyznania prawosławnego:

Ja tedy władzą starszeństwa mego, a imieniem wojskowem w. m. rozkazuje i upominam, abyście nie byli bezpiecznymi lekce sobie tego nie ważyli, a po gotowiu byli,

${ }^{17}$ Warto wymienić prace: Tomkiewicz 1930b: 132-133; Wójcik 1961: 117-119; Serczyk 1984: 330-332; Sysyn 1985: 82-84; Щербак 1989: 52-57; Грушевський 1995b: 239-246; Jakowenko 2000: 200; Ляx 2002c: 392-293; Franz 2005: 210-242; Gawęda 2007: 11-198.

${ }^{18}$ Wójcik zupełnie neguje czynnik religijny w powstaniu: „,charakter powstania był na wskroś społeczny, religia nie odgrywała w nim żadnej roli, o narodowych hasłach w ogóle nie można było mówić" (1989: 57). Również Serczyk pomija te kwestie (1984: 332-339). Ich rolę podkreśla zaś Грушевський (1995b: 259-276), dostrzega je Sysyn (1985: 85-86), Щербак (1989: 52-69), Plokhy (2001:141-143), a szczegółowo omawia Drozdowski (2008: 196-200).

${ }^{19}$ K.P. Skidan do Kozaków, Łubnie, 11 października 1637 roku (Національна бібліотека України ім. В.І. Вернадського [Київ], [dalej: НБУВ], f. II-13402: 327). 
tak końmi jako i leguminami i orężem też, przeciw temu przeciwnikowi wiary naszej greckiej mężnie się stawili; tego potrzeba ukazuje (Okolski 1858a: 26).

Postulaty religijne zawierają też dwa inne uniwersały: Skidana ${ }^{20}$ i hetmana Pawluka ${ }^{21}$. Potwierdza je korespondencja Mikołaja Potockiego $\mathrm{z}$ hetmanem Koniecpolskim np. z 10 grudnia $1637 \mathrm{roku}^{22}$.

Losy powstania i samego Pawluka rozstrzygnęła bitwa pod Kumejkami 16 grudnia 1637 roku, zakończona klęską Zaporożców (Tomkiewicz 1937: 239-261), po której podpisano porozumienie borowickie. Duchowieństwo prawosławne miało raczej sceptyczny stosunek do wysuwanych wtedy haseł religijnych (Plokhy 2001: 143), ale wcale nie musi to dowodzić, że użyto ich w celach wyłącznie propagandowych. Moim zdaniem, było to kolejne już świadectwo samodzielności i bezkompromisowości Niżowców w polityce wyznaniowej.

Dziesiątego marca 1638 roku sejm zwyczajny uchwalił konstytucję Ordynacja wojska zaporoskiego regestrowego w stużbie Rzeczypospolitej będacego, mającą uregulować kwestie kozackie. Postanowiono m.in. zmniejszyć rejestr do 6 tys., a resztę Kozactwa pozbawić praw i obrócić w chłopów pańszczyźnianych ${ }^{23}$. Wbrew oczekiwaniom Kozacy nie zamierzali się podporządkować konstytucji godzącej w ich interesy. Zerwali się ponownie do walki pod przewodnictwem Jakuba Ostrzanina (Щербак 1989: 363); walka ta miała także zabarwienie religijne. Na szczególną uwagę zasługuje treść uniwersału, który w przededniu „,buntu” jego przywódca skierował do całego „narodu” ruskiego (Кулиш 1994: 293-307). Wzywając w nim do zbrojnego wystąpienia przeciw Rzeczypospolitej,

${ }^{20}$ K.P. Skidan do Kozaków, Moszen, 29 listopada 1637 roku (Okolski, 1858a: 26-27).

${ }^{21}$ P.M. Pawluk do Kozaków, Moszen, 15 grudnia 1637 roku (Okolski 1858a: 46-47).

22 „(...) bardzo się po Zadnieprzu hultajstwo mocni, i jusz prawie co chłop to Kozak. Uniwersały skidanowe po miasteczkach, miastach i wsiach, jeden za drugim latają, aby się dniem i nocą konni i pieszy wszędzie kupili i do niego przybywali, ukazując im, jako pogodny czas mają dopinania na nas wolności swoich, jako teraz znioszy wojsko nasze, na wiosnę zmocnić i ugruntować się mogą przeciwko nam duszmanom i nieprzyjaciołom wiary swej, jako nas nazywają" (НБУВ, f. II-13402: 371-372).

${ }^{23}$, ,...) wszelkie tedy ich dawne prawa, starszeństwa, prerogatywy, dochody i insze godności przez wierne posługi ich od przodków naszych nabyte, a teraz przez tę rebelią stracone na wieczne czasy im odejmujemy, chcąc mieć tych, którzy losy wojny pozostawiły wśród żywych, za chłopy obrócone pospólstwo" (Ohryzko 1859: 440). 
hetman kozacki zwraca uwagę na konieczność obrony Kościoła prawosławnego przed nieustającym naporem unii:

А что̀ всего важнђе такъ ето то, что эти непріятели наши, отступники и еретики Ляхи, стараются перемънить, привести къ Римскому заблужденію, обратить и насильно преклонить къ Уніи и самую хвалу Божію, которая совершается оть начала крещеня Руси и, какъ солнце, сіяетъ въ Европъ незыблемымъ благочестіемъ; и уже въ нъкоторыхъ Украінскихъ городахъ естъ знаки и свидђтельства этого ихъ посягательства (Кулиш 1994: 302).

Interesująca jest podana przez Szymona Okolskiego informacja o wysłaniu przez Kozaków licznych listów do monasterów oraz o agitacji duchowieństwa prawosławnego na rzecz poparcia wojny z Rzecząpospolitą (Borowiak 2010: 9-163; Щербак 1989: 72; Drozdowski 2008: 202-205). Mimo że nie znamy pełnej zawartości wspomnianych pism, nic nie wiemy o używanych przez duchowieństwo argumentach, wydaje się prawdopodobne, że w obu wypadkach nacisk położono na krzywdy, które stały się udziałem Cerkwi prawosławnej pod panowaniem Rzeczypospolitej.

Religijne elementy powstania pod wodzą Ostrzanina wskazują zagraniczni obserwatorzy wydarzeń w Rzeczypospolitej. „Gazette de France” z września 1638 roku doniosła, że zbuntowani Kozacy wysłali petycję do króla, w której godzili się na zawarcie pokoju pod warunkiem spełnienia trzech najważniejszych dla nich postulatów - najpierw zagwarantowania im swobód wyznaniowych, potem przywrócenia praw i przywilejów odebranych na ostatnim sejmie warszawskim („Gazette de France” 1638: 621).

Dość przewrotnie wyznaniowy charakter wystąpienia potwierdza sporządzona w kwietniu relacja putywlskiego wojewody dla cara. Powołując się na informacje od Stanisława Potockiego, donosił on o walkach, których główna przyczyna wynikała z samowoli wojska zaporoskiego, nie zaś z powodów religijnych: „побиваютъ [jak mówił Potocki - M.R.D.] де онъ казаковъ зе самоволство, а не за вьру" (Акты относящиеся 1861: 3).

Kapitulacja obozu kozackiego na uroczysku Starzec zadecydowała o upadku powstania. Podczas rady kijowskiej 9 września 1638 roku (Okolski 1858b: 187-188) Kozacy zredagowali instrukcję dla swych posłów udających się do króla Władysława IV, w której wpisali też postulaty wyznaniowe (Грушевскій: 1995b: 312-314). Oprócz próśb o zachowanie 
przywilejów i wolności, wnoszono o zwrot dóbr monasteru Trechtymirowskiego ${ }^{24}$.

Obecność postulatów religijnych w powstaniach kozackich pierwszej połowy XVII wieku niewątpliwie potwierdza zaangażowanie Kozaczyzny w walkę o przywrócenie Cerkwi prawosławnej należnych jej praw i dowodzi, że pełniła ona funkcję obrońcy wyznaniowych interesów społeczności ruskiej, przeciwstawiając się prounijnej polityce państwa.

Wysuwane przez Kozaków w trakcie wystąpień zbrojnych żądania natury wyznaniowej nie pozostawały bez wpływu na postawy uczestników zapoczątkowanego przez synod brzeski konfliktu religijnego. Najdobitniejszym tego przykładem jest powstanie pod wodzą Tarasa Fedorowicza, które wywarło istotny wpływ na pojawienie się na sejmikach odbywanych przed sejmem 1631 roku postulatów związanych z uregulowaniem spraw „religii greckiej”. Dotyczy to m.in. sejmików w Łucku, Wiśni oraz Żytomierzu (Mironowicz 1997: 49). Znaczenie akcentów wyznaniowych w tym powstaniu dostrzegli również senatorowie Rzeczypospolitej, którzy na wspomnianym sejmie, odnosząc się do kwestii kozackiej, postulowali uregulowanie spraw Kościoła prawosławnego (Drozdowski 2008: 191).

\section{Literatura}

\section{Źródła rękopiśmienne}

Archiwum Główne Akt Dawnych, Archiwum Radziwiłłów, dział II, nr 1025.

Biblioteka Książąt Czartoryskich w Krakowie, rkps 117.

„Gazette de France” 1638 mikrof. Biblioteki Narodowej, nr 52656.

Національна бібліотека України ім. В.І. Вернадського (Київ), f. II - 13402.

\section{Źródla drukowane}

Niemcewicz J.U., 1833, Zbiór pamiętników historycznych o dawnej Polscze, z rękopisów, tudzież dziet w różnych językach o Polscze wydanych, t. VI, Lwów.

${ }^{24}$ „Strony monastera naszego Trechtymirowskiego, którychmy mieli z dawnych czasów z nadaniem kilkoma wsiami na nabożeństwo do Cerkwi Bożej, teraźniejszego czasu JM P strażnik coronny trzy wsi tych, mianowicie Kobescza, Nowy Druchczyn, i Romaszki, na siebie wziąc kazał (...) a Pan Proskura pisarz ziemski kijowski tesz gwałtem wieś czwartą Hryhorowkę odjął i inszych sieła krzywd nieznośnych pomieniona Cerkiew Boża od dwu Jch M ponosi, o czym pilnie a słusznie prosić J.K.M. PNM, aby pomienione te wsi wszystkie do onej Cerkwie Bożej przywrocone bydz mogły” (НБУВ, f. II-13402: 408). 
Ohryzko J., 1859, Volumina Legum, t. III, Petersburg.

Okolski S., 1858a, Dyaryusz transakcyi wojennej między wojskiem koronnem i zaporoskiem w r. 1637 r., wyd. K.J. Turowski, Kraków.

Okolski S., 1858b, Kontynuacya dyaryusza wojennego w roku 1638 odprawiona, wyd. K.J. Turowski, Kraków.

Piasecki P., 1870, Kronika Pawła Piaseckiego biskupa przemyślskiego..., wstęp i oprac. J. Bartosiewicz, Kraków.

Przeździecki A., Malinowski M., 1844, Źródła do dziejów polskich, t. II, Wilno.

Wójcicki K.W., 1846, Pamiętniki do panowania Zygmunta III, Władysława IV i Jana Kazimierza, t. I, Warszawa.

Акты, относящиеся к истории Южной и Западной России, собранные и изданные Археографическою комиссиею, 1861, т. III, 1638-1657, Санктпетербург.

Бевзо О.А., 1971, Львівський літопис і Острозький літописеиь: Джерелознавче дослідження, вид. 2, Київ.

Крип'якевич I., 1908, Жерела до історї Украӥни-Руси, т. 8, Матеріали до історії української козаччини, т. 1, Документи по рік 1631, Львів.

Кулиш П.А., 1877, Материаль для истории воссоединения Руси, т. I, 1578-1630, Москва.

Кулиш П.А., 1994, Записки о Южной Руси, т. II, Киев.

\section{Opracowania}

Borowiak A., 2010, Powstanie kozackie 1638, Zabrze.

Chodynicki K., 1934, Kościół prawosławny a Rzeczpospolita polska. Zarys historyczny 1370-1632, Warszawa.

Chynczewska-Hennel T., 1985, Świadomość narodowa szlachty ukraińskiej i Kozaczyzny od schytku XVI do połowy XVII w., Warszawa.

Chynczewska-Hennel T., 1994, Spory wokół Unii brzeskiej (koniec XVI-XVII wiek), w: „Warszawskie Zeszyty Ukrainoznawcze” z. 2, Spotkania polsko-ukraińskie. Studia Ucrainica, red. S. Kozak, Warszawa, s. 28-34.

Drozdowski M.R., 2004, Kozaczyzna wbrew hierarchii prawosławnej - 1625 rok, „Warszawskie Zeszyty Ukrainoznawcze” z. 17-18, Spotkania polsko-ukraińskie. Studia Ucrainica Varsoviensia, red. S. Kozak, Warszawa, s. 379-388.

Drozdowski M.R., 2008, Religia i Kozaczyzna Zaporoska w Rzeczypospolitej w pierwszej połowie XVII wieku, Warszawa.

Drozdowski M.R., Chynczewska-Hennel T., 2008, Kozaczyzna w Rzeczypospolitej XVI-XVII wieku. Jeszcze jeden stan społeczeństwa staropolskiego, „Społeczeństwo Staropolskie. Seria nowa”, t. I, Społeczeństwo a polityka, s. 165-221.

Floria B., 1992, New Evidence on the 1630 Zaporozhian Cossack Uprising, „Harvard Ukrainian Studies" nr 1-2, t. XVI, s. 167-173.

Floria B., 1998, Nowe materiaty do dziejów powstania kozackiego z 1625 roku, „Przegląd Wschodni” t. V, z. 1 (17), s. 27-42. 
Franz M., 2005, Powstanie kozackie 1637 r., „Україна в Центрально-Східній Європі” вип. 5, s. 210-242.

Franz M., 2006, Idea państwa kozackiego na ziemiach ukrainnych w XVI-XVII wieku, Toruń.

Gawęda M., 2007, Powstanie kozackie 1637, Zabrze.

Jakowenko N., 2000, Historia Ukrainy od czasów najdawniejszych do końca XVIII wieku, przeł. O. Hnatiuk, K. Kotyńska, Lublin.

Kempa T., 2003, Sprawa zabójstwa wójta kijowskiego Teodora Chodyki przez Kozaków. Przyczynek do wyjaśnienia sytuacji na Kijowszczyźnie w przededniu powstania kozackiego 1625 r. (Publikacja źródet), w: Między Zachodem a Wschodem, red. J. Dumanowski, B. Dybaś, K. Mikulski, J. Poraziński, S. Roszak, t. II, Toruń, s. 289-300.

Kempa T., 2007, Wobec kontrreformacji. Protestanci i prawostawni w obronie swobód wyznaniowych w Rzeczypospolitej w końcu XVI i w pierwszej polowie XVII wieku, Torun.

Kroll P., Nagielski M., Wagner M., (red.), 2010, Hetmani zaporoscy w stużbie króla i Rzeczypospolitej, Zabrze.

Lewicki K., 1934, Sprawa unii Kościoła wschodniego z rzymskim w polityce dawnej Rzeczypospolitej, Warszawa.

Mironowicz A., 1997, Prawosławie i unia za panowania Jana Kazimierza, Białystok.

Mironowicz A., 2001, Kościót prawosławny w dziejach dawnej Rzeczypospolitej, Białystok.

Plokhy S., 2001, The Cossacks and Religion in Early Modern Ukraine, Oxford.

Serczyk W.A., 1984, Na dalekiej Ukrainie. Dzieje Kozaczyzny do 1648 roku, Kraków.

Sysyn F.E., 1982, Stosunki ukraińsko-polskie w XVII wieku; rola świadomości narodowej $i$ konfliktu narodowościowego w powstaniu Chmielnickiego, „Odrodzenie i Reformacja w Polsce" t. XXVII, s. 67-92.

Sysyn F.E., 1985, Between Poland and the Ukraine. The Dilemma of Adam Kysil, 1600-1653, Cambridge.

Tomkiewicz W., 1930a, Powstanie kozackie w roku 1630, „Przegląd Powszechny” t. CLXXXVII, s. 121-123.

Tomkiewicz W., 1930b, Powstanie kozackie w roku 1630, Kraków.

Tomkiewicz W., 1937, Bitwa pod Kumejkami (16 XII 1637), „Przegląd Historyczno-Wojskowy" t. IX, z. 2, s. 239-261.

Wójcik Z., 1961, Dzikie Pola w ogniu. O Kozaczyźnie w dawnej Rzeczypospolitej, Warszawa.

Wójcik Z., 1989, Wojny kozackie w dawnej Polsce, Warszawa.

Брехуненко В., 1998, Стосунки украӥнського козаитва з Доном у XVI-середині XVII cm., Київ-Запоріжжя.

Брехуненко В., 2011, Козаки на степовому кордоні Європи: Типологія козацьких спільнот XVI-першої половини XVII cm., Київ. 
Грушевський М., 1995a, Історія України-Руси, т. VII, Козаиькі часи до року 1625, Київ.

Грушевський М., 1995b, Iсторія Украӥни-Руси, т. VIII, Роки 1626-1650, ч. 1, Вid Куруківщини до Кумейщини (роки 1626-1638), Київ.

Жукович П., 1910, Сеймовая борьба западно-русского дворянства с иерковной унией (с 1609 г.), т. V, Санкт-Петербург.

Жукович П., 1911, Религиозно-иерковный элемент в казаиком восстании 1630 года (Под предводительством Тараса), „Христианское чтение” $\mathrm{nr}$ 9, t. CCXXXVI, s. $987-1007$.

Коробов О.І., 2002, Чорний Григорій (Грицько) Савич, w: Українське козаитво: Мала енциклопедія, ред. Ф.Г. Турченко, Київ.

Леп'явко С., 1996, Козаиькі війни кіния XVI cm. в Украӥні, Чернігів.

Лях С.Р., 2002а, Повстання 1625, w: Українське козаитво: Мала енииклопедія, ред. Ф.Г. Турченко, Київ, s. 389-391.

Лях С.Р., 2002b, Повстання 1630, w: Украӥнське козаитво: Мала енциклопедія, ред. Ф.Г. Турченко, Київ, s. 391-392.

Лях С.Р., 2002c, Повстання 1637, w: Українське козаитво: Мала еничиклопедія, ред. Ф.Г. Турченко, Київ s. 392-393.

Рудницький С., 1897, Козаџько-польська війна 1625 року, „Записки наукового товариства ім. Т. Шевченка", т. XVII.

Щербак В.О., 1989, Антифеодальні рухи на Україні напередодні визвольної війни 1648-1654 рр., Київ.

Щербак В.О., 2000, Українське козачтво: формування соиіального стану. Друга половина $X V$-середина XVII cm., Київ. 